\title{
HUBUNGAN PENGETAHUAN DENGAN PERILAKU SADARI (PERIKSA PAYUDARA SENDIRI) SEBAGAI TINDAKAN DETEKSI DINI KANKER PAYUDARA PADA SISWI KELAS X DI SMA NEGERI 3 KOTA PADANGSIDIMPUAN
}

\author{
Nurhanifah Siregar \\ STIKes Darmais Padangsidimpuan \\ nurhanifahsiregar90@gmail.com
}

\begin{abstract}
Breast cancer is a type of malignant tumor that is still the number one killer. Indonesia at first breast cancer attacks women aged over 30 years, but now the age of breast cancer patients becomes young or teenagers. Breast cancer can be found as early as BSE. If you don't do BSE breast cancer will be detected at an advanced stage and ultimately cause death. Early detection can reduce mortality by 25-30\%. Breast selfexamination is very important to be recommended for the community or adolescents because almost $86 \%$ of lumps in the breast are found by patients themselves. This type of research is an analytical survey with cross sectional design, a sample of 45 people. The measuring instrument is a questionnaire with 22 questions developed by researchers. This study aims to determine the relationship between independent and dependent variables. The analysis used is univariate analysis to see the description of the characteristics of respondents and bivariate tests using Chisquare. The results showed that there was no relationship between knowledge and conscious behavior $(P$-value $=$ 0.487, where P-value was 5 0.05). It was emphasized with the results of the study, there were 34 students with only 1 knowledgeable behavior. With that, good student knowledge will not necessarily understand good BSE behavior. It could be less knowledgeable but understand good BSE behavior.Based on the results of this study, suggestions for students to care more about their health, more often to check their own breasts after each menstrual period - 7 to 10 days from the first day of menstruation, reduce the habits of fast food patterns because it will accelerate the trigger of breast cancer.
\end{abstract}

\section{Keywords: BSE Behavior, Early Detection, Breast Cancer}

\section{PENDAHULUAN}

Pada masa remaja berlangsung proses proses perubahan fisik maupun biologis yang dalam perkembangan selanjutnya berada di bawah kontrol hormon-hormon khusus. Pada wanita hormon ini berfungsi dari permulaan proses ovulasi dan menstruasi, juga pertumbuhan payudara. Pada masa ini sudah seharusnya para remaja puteri di mulai memperhatikan perubahan yang terjadi. Sebaiknya pemeriksaan dapat dimulai dari waktu remaja dan pemeriksaan yang rutin dan teratur untuk mendeteksi tanda-tanda dini pada payudara (Putri, Ladjar, \& Rahmayani, 2017).

Kanker payudara merupakan jenis tumor ganas yang hingga kini masih menjadi pembunuh nomor satu bagi perempuan. Hal ini dibuktikan dengan adanya diagnosis baru yang dicatat oleh 
WHO bahwa kasus kanker hampir 1,7 juta pada tahun 2012, ini mewakili sekitar $12 \%$ dari semua kasus kanker baru dan $25 \%$ dari semua kanker pada wanita(Putri et al., 2017).

Seiring perkembangan zaman, jumlah penderita kanker di Indonesia terus bertambah. Pada awalnya kanker payudara menyerang perempuan yang berusia diatas 30 tahun akan tetapi kini usia penderita kanker payudara menjadi ke perempuan yang berusia muda atau remaja. Kanker

payudara (Carcinoma mammae) merupakan suatu kondisi dimana sel telah kehilangan pengendalian dan mekanisme normalnya, sehingga terjadi pertumbuhan yang tidak normal, cepat dan tidak terkendali yang terjadi pada jaringan payudara(Sinaga \& Ardayani, 2016).

Data tahun 2012 yang diperoleh dari ruang rekam medis Rumah Sakit Umum Daerah dr. Zainoel Abidin (RSUDZA). Banda Aceh pada bulan Januari hingga Desember 2011 sebanyak 524 kasus yang terkena neoplasma ganas kanker payudara yang diantaranya berusia 15-24 tahun sebanyak 12 kasus (2,3\%) (Sinaga \& Ardayani, 2016).

Berdasarkan survey pendahuluan yang dilakukan di kelas X SMA Negeri 3 Padangsidimpuan. Dengan melakukan wawancara kepada 10 siswi, "Apakah mereka pernah melakukan tindakan SADARI (Periksa Payudara Sendiri) ?’. Dari hasil wawancara dengan 10 siswi tersebut mengatakan belum pernah melakukan SADARI (Periksa Payudara Sendiri).

Penelitian ini bertujuan untuk mengetahui. hubungan pengetahuan dengan perilaku sadari (periksa payudara sendiri) sebagai tindakan deteksi dini kanker payudara pada siswi kelas $\mathrm{X}$ di SMA Negeri 3 Kota Padangsidimpuan.

\section{METODE}

Jenis penelitian ini merupakan penelitian survey analitik dengan rancangan cross sectional. Populasi dalam penelitian ini adalah seluruh Remaja siswi kelas $\mathrm{X}$ di SMA Negeri 3 Kota Padangsidimpuan yaitu sebanyak 223 orang siswi. Sampel dalam penelitian ini sebanyak 45 orang siswa dengan menggunakan menggunakan teknik random sampling dengan mengambil 20\% dari populasi.

Aspek Pengukuran data dalam penelitian ini adalah pengetahuan dikategorikan dengan Baik, apabila subjek mampu menjawab soal dengan benar sebanyak 9 - 16 soal yaitu $50 \%$ $100 \%$ dari seluruh pertanyaan, kurang apabila subjek mampu menjawab soal dengan benar sebanyak 1-8 soal yaitu 45 $\%$ - $50 \%$ dari seluruh pertanyaan. Perilaku dikategorikan menjadi baik, apabila subjek mampu menjawab dengan benar sebanyak 4 - 6 soal, dan kurang Baik, apabila subjek mampu menjawab dengan benar sebanyak $1-3$ soal. 


\section{HASIL DAN PEMBAHASAN}

\section{Hasil Penelitian}

Tabel 1. Distribusi Frekuensi karaktaristik responden terhadap SADARI (Periksa Payudara Sendiri) pada siswi kelas X

\begin{tabular}{|c|c|c|}
\hline Pengetahuan & $\mathbf{f}$ & $\%$ \\
\hline Baik & 6 & 13,3 \\
\hline Kurang & 39 & 86,7 \\
\hline Total & 45 & 100 \\
\hline Perilaku & $\mathbf{F}$ & $\%$ \\
\hline Baik & 9 & 20.0 \\
\hline Kurang Baik & 36 & 80,0 \\
\hline Total & 45 & 100 \\
\hline $\begin{array}{l}\text { Berdasarkan tabel diatas } \\
\text { tentang pengetahuan siswi kelas } \mathrm{X} \\
\text { terhadap SADARI menunjukkan bahwa } \\
\text { mayoritas responden berpengetahuan }\end{array}$ & & $\begin{array}{l}\text { terhadap sebanyak } 36 \\
\text { dan minoritas responden } \\
\text { xu Baik yaitu sebanyak } 9\end{array}$ \\
\hline
\end{tabular}

kurang yaitu 39 orang $(86,7 \%)$ dan

minoritas responden berpengetahuan

baik yaitu 6 orang $(13,3 \%)$. Untuk

Tabel 2. Hubungan Pengetahuan Dengan Perilaku Sadari (Periksa Payudara Sendiri) Sebagai Tindakan Deteksi Dini Kanker Payudara Pada Siswi Kelas

\section{Perilaku SADARI}

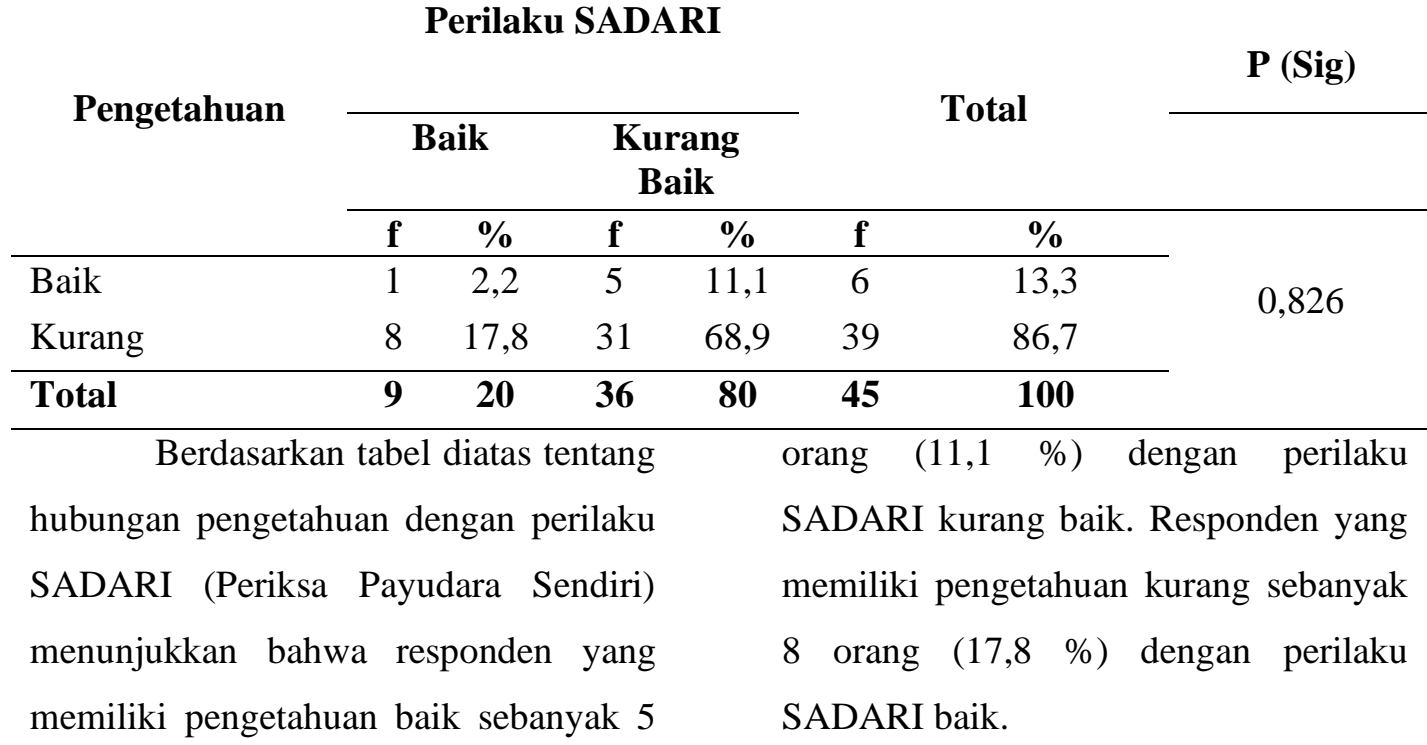


Berdasarkan uji chi - square diperoleh nilai Pvalue $=0,826$ dimana nilai $P$ value $\geq 0,05$ yang berarti tidak ada hubungan antara pengetahuan dengan perilaku SADARI.

\section{PEMBAHASAN}

$\begin{array}{cc} & \text { Berdasarkan hasil tabulasi } \\ \text { silang antara pengetahuan dengan }\end{array}$ prilaku SADARI di SMA Negeri 3 Kota Padangsidimpuan tahun 2018 dengan uji chi - Square diperoleh nilai Pvalue $=$ 0,826 dimana nilai Pvalue $\geq 0,05$ yang menandakan hipotesis di tolak yang artinya tidak ada hubungan antara pengetahuan dengan perilaku SADARI (Periksa Payudara Sendiri). Hal itu dipertegas dengan data yang ditemukan bahwa responden yang memiliki pengetahuan baik sebanyak 5 orang $(11,1 \%)$ dengan perilaku SADARI kurang baik. Hal ini tidak sejalan dengan teori (Notoatmodjo, 2003) yang menyatakan jika seseorang dengan pengetahuan tinggi maka orang tersebut semakin luas pengetahuannya. Akan tetapi seseorang yang berpendidikan rendah mutlak berpengetahuan rendah pula. Dan responden yang memiliki pengetahuan kurang sebanyak 8 orang $(17,8 \%)$ dengan perilaku SADARI baik, dikarenakan bahwa reponden yang memiliki pengetahuan kurang tidak mengetahui secara umum gejala dari Kanker payudara tersebut. Hal itu dapat dipastikan pengetahuan reponden yang kurang tentu akan berdampak pada kanker payudara.

Hasil penelitian sesuai dengan penelitian yang dilakukan oleh (Puspita, 2016) Bahwa tidak ada hubungan pengetahuan dengan perilaku SADARI dikarenakan Mahasiswi yang mempunyai pengetahuan cukup baik namun tidak melaksanakan SADARI dalam hal ini disebabkan karena mahasiswa tersebut merasa malas dan kurang memperhatikan cara melakukan SADARI sewaktu diterangkan sehingga mereka tidak tahu benar cara melakukannya.

Berdasarkan hasil penelitian (Sari \& Tanjung Anitasari, 2017) Berdasarkan hasil uji chi-square didapatkan nilai $p$-value $=0,380$ dimana nilai $\mathrm{p}$ - value $\geq 0,05$ sehingga dapat disimpulkan bahwa tidak ada hubungan antara pengetahuan dengan perilaku SADARI mahasiswi kesehatan masyarakat di Universitas Muhammadiyah Surakarta.

Menurut asumsi peneliti hal ini terjadi disebabkan karena pengetahuan tinggi tidak selamanya sejalan dengan perilaku yang baik. Hal itu dipertegas dengan data yanag ditemukan bahwa responden yang memiliki pengetahuan baik sebanyak 5 orang $(11,1 \%)$ dengan perilaku SADARI kurang baik.dan Responden yang memiliki pengetahuan 
kurang sebanyak 8 orang $(17,8 \%)$ dengan perilaku SADARI baik.

Menurut asumsi peneliti bahwa dengan pengetahuan siswi yang baik belum tentu akan mengerti tentang perilaku SADARI yang baik. Bisa saja yang berpengetahuan kurang tetapi mengerti tentang perilaku SADARI yang baik. Faktor lain yang bisa terjadi dalam mempengaruhi perilaku SADARI seperti kebiasaan pola makan yang tidak sehat, seperti mengkonsumsi makanan yang siap saji. Padahal makanan siap saji akan lebih cepat untuk memicu terjadinya kanker payudara.

Mereka lebih sering mengabikan karna merasa tidak perlu dan merasa malas untuk memeriksakannya pada setiap kali selesai menstruasi yaitu hari ke -7 sampai ke -10 terhitung hari pertama haid, padahal pada saat ini pengaruh hormonal estrogen dan progesteron sangat rendah dan jaringan kelenjar payudara saat itu tidak membengkak sehingga lebih muda meraba adanya tumor ataupun kelainan pada payudara. Tetapi masih ada yang melakukan SADARI kurang dari 12 kali. Ini menjelaskan bahwa masih kurangnya kesadaran para siswi tentang melakukan SADARI setiap satu bulan sekali dalam setahun dengan rutin.

\section{KESIMPULAN DAN SARAN}

Tidak ada hubungan antara pengetahuan dengan perilaku SADARI (Periksa Payudara Sendiri) sebagai tindakan deteksi dini kanker payudara pada siswi kelas $X$ di SMA Negeri 3 Kota Padangsidimpuan Tahun 2018, dimana hasil Chi - square di peroleh nilai $\mathrm{P} v a l u e=0,826$ (Pvalue $\geq 0,05)$.

Diharapkan bagi responden yaitu siswi kelas X di SMA Negeri 3 Kota Padangsidimpuan tidak hanya meningkatkan pengetahuan tentang SADARI sebagai tindakan deteksi dini kanker payudara, namun juga sebaiknya dijadikan perilaku dasar untuk menerapkan dan melakukan gaya hidup sehat secara rutin.

\section{DAFTAR PUSTAKA}

Notoatmodjo, S. (2003). Ilmu kesehatan masyarakat, rineka cipta. Jakarta.

Puspita, N. D. (2016). Faktor Yang Berhubungan Dengan Perilaku Sadari Pada Mahasiswi Fakultas Non Kesehatan Di Universitas Hasanuddin. Skripsi Program Studi Ilmu Kesehatan Masyarakat. Makassar: Universitas Hasanuddin.

Putri, E. L. A., Ladjar, I. I., \& Rahmayani, D. (2017). Gambaran tingkat pengetahuan remaja putri tentang pemeriksaan payudara sendiri (sadari) di smp anggrek 
banjarmasin. Jurnal keperawatan suaka INSAN (JKSI), 2(1), 1-6.

Sari, N. K., \& Tanjung Anitasari, I. K. (2017). Faktor-faktor yang Berhubungan dengan Perilaku Pemeriksaan Payudara Sendiri (SADARI) pada Mahasiswi Kesehatan Masyarakat di Universitas Muhammadiyah Surakarta. Universitas Muhammadiyah Surakarta.

Sinaga, C. F., \& Ardayani, T. (2016). Hubungan Pengetahuan dan Sikap Remaja Putri Tentang Deteksi Dini Kanker Payudara Melalui Periksa Payudara Sendiri di SMA Pasundan 8 Bandung Tahun 2016. Kartika: Jurnal Ilmiah Farmasi, 4(1), 16-19. 